\title{
THE ANALOGY BETWEEN THE DOCTORS' IN- VOLVEMENT IN CAPITAL PUNISHMENT AND THE PRIEST'S INVOLVEMENT IN WAR
}

\author{
Joseph BR Gaie \\ Department of Theology and Religious Studies \\ University of Botswana
}

\begin{abstract}
There does seem to be an analogy between the involvement of doctors in capital punishment and that of priests in war. For both there is a prima facie contradiction between what they stand for and their involvement in war and capital punishment. However, there are situations which might justify the apparent abandonment of the basic principles of the two professions. The question which seems to arise for the two is whether in pursuing their principles they do not violate other morally important conditions presupposed by the profession.
\end{abstract}

Keywords: Capital punishment, Medical doctors, Priests, War

\section{Introduction}

There seems to be a relationship between the involvement of doctors in capital punishment and that of priests in war. For the two there is an apparent contradiction in what they stand for and what is implied by their involvement in the two practices of war and capital punishment. There is also a similarity between the two in that the priest is for peace which ultimately is for the good of humanity. That is, he would not approve the killing of human beings. The doctor also stands for the good of human beings in that he makes sure that they live. In other words, the two would prima facie have problems with practices which seem to undermine their vocations.

The question to ask is whether, given the aim of medicine as the preservation of life and that of priesthood being the bringing about of peace, the two can be involved in the practices of capital punishment and war? That is, should a doctor participate in the execution of a prisoner? Should a priest participate in war?

There are ways in which these can be said to participate. The priest can participate in the army by being a chaplain. That would include counseling soldiers; praying with and for them both at home and at the front; before and after the battle; donning on combat gear at times and even carrying a gun; helping with ideas to avoid detection by enemy forces and obeying commands of the senior officers. In short, he is some type of soldier.

The doctor's participation includes giving expert advice in a murder trial; treating the prisoner so as to be executed in a healthy condition; aiding the actual execution by giving advice as to the amount of gas or poison that is to be administered; recommending the type of execution; giving details of an effective way of hanging and certifying the death of the prisoner.

This essay aims to assess that relationship between the two vocations in as far as there can be an analogy between them. In other words, the first part is to ask whether the two are analogues or not. This depends in my view on whether there is a significant difference be- 
tween the two or not. This necessitates a proper understanding of the word "analogy". Analogues are things which are significantly similar to each other and also different from each other. An analogy is the relationship of the analogues. An analogy is a relationship of both similarity and difference. The similarity must be adequate to such an extent that it is noticeable without difficulty and the difference(s) must be such that they do not overshadow the similarities in terms of their pronouncement. To say that a word is used analogically is to mean that it is both similar and different in meaning as it is applied to two different things. For example the word "being" is used analogically when applied to both me and a piece of stone. Both the stone and I are beings in exactly the same sense. That is, we are things in existence. But there is a difference between me and the stone in that I am a sentient sort of being while the stone is a non-sentient kind of being. Even the word "stone" is used analogically in the sense that any stone shares significant qualities with all other stones, but it is different in that it is 'this particular stone' and not any other one.

\section{Demands of the Vocation (Prohibition against Killing)}

\section{The Priest and War}

A priest, at least a Christian priest, is perceived as one who stands for the universal brotherhood of humanity. One who preaches that there should be peace among human beings as children, sons and daughters of God following the exemplary teaching of Jesus. This brotherhood/sisterhood involves forgiveness and love among all. Above all, the priest is one who stands for the commands of God, one of which is that there should not be killing of human beings.

Based on the teaching of Christ as construed from the Bible, it appears at least many forms of killing human beings are unacceptable. This is evident because "the idea that war must be renounced comes from Christianity. The serious rejection of war as such, in contrast to a more general rejection of violence, does not appear before the Christian era" (Teichman, 1986:10).

The other argument is that in spite of the acceptance of war for different reasons in Christianity nowadays, the early Christians did not accept war. They did not engage in warfare. That was the case for the whole and part of the first and second centuries AD. This was mainly because Christianity, as an offshoot of Judaism, did not have its members engage in military service since Jews were exempted. However, the situation changed when Constantine was converted to Christianity. Seen as a good Christian king, there was need to justify refusal to protect his kingdom by Christians who until then had suffered persecution at the hands of many Roman emperors. But even then war was not to be accepted by all the Christians and for all times. Harnack was quoted as having said that:

the position of a soldier would seem to be still more incompatible with Christianity than the higher offices of state, for Christianity prohibited on principle both war and bloodshed" (MCII “...the Christ forbade war absolutely to the Christians"), 47f: "Had not Jesus forbidden all revenge, even all retaliation for wrong and taught complete gentleness and patience? and was not the military calling more over contemptible on account of its exortions, acts of violence, and police service? Certainly: And from that it followed without question, that a Christian might not of his free will become a soldier. It was not difficult to keep to this rule, and certainly the oldest Christians observed it" (Cadoux, 1919:97).

Again:

One simple and common argument for pacifism is the argument that the Bible, God's revealed work, says to all people: "Thou shalt not kill" (Exod. 20:13). Some pacifists interpret 
this sentence as implying that no-one should kill under any circumstances, unless God indicates that this command is suspended, as $\mathrm{He}$ did when $\mathrm{He}$ commanded Abraham to slay Isaac. The justification for this interpretation is the words themselves, "Thou shalt not kill", which are presented in the Bible bluntly and without qualification, not only in Exodus but also in Deuteronomy (5:17) (Lackey, 1989:8).

He goes on:

Ye have heard that it hath been said, an eye for an eye, a tooth for a tooth: But I say unto you, that ye resist not evil: But whosoever shall smite thee on the right cheek, turn to him the other also... Ye have heard it said, thou shalt love they neighbour, and hate thine enemy. But I say unto you, love your enemies, bless them that curse you, do good to them that hate you ...that ye may be the children of your father which is in heaven: For he maketh the sun to rise on the evil and on the good, and sendeth the rain on the just and the unjust (Matt. 5:38 45) (Lackey, 1989:11).

"Some Christians have believed that although war was permissible in Old Testament times it ceased to be allowable after the new teaching of Jesus" (Teichman, 1986:5).

Basically the teaching of Christianity is that of peace, love and forgiveness. The priest is the one who has dedicated his life to the spreading of that message. Christianity stands for justice (at least it should) and fairness. It stands for the betterment of the human condition. This includes all social structures, institutions and movements which should improve the life of human beings. Christianity should help seek human happiness. That means a good government has to be not only supported by obeyed by the Christian. This means even laws will be obeyed. Such a government has to be protected from the destructive forces of anarchy and unjust criticism. Likewise, a Christian not only has to agree with genuine efforts of peace-making but to participate as far as possible, in the preservation and expansion of such efforts.

The problem with war is that it flies right into the face of the Christian conscience. It is apparently inconsistent with the ideals of Christianity. It involves the killing of human beings. If some are guilty (whatever they are guilty of such that they can be killed in war), others are innocent (at least of that which the others are guilty). Some are maimed and crippled. If some are enemies others are friends, and yet war kills them. Christianity, as shown above, at least apparently calls for the love not only of friends and relatives, but of enemies as well. Does loving somebody mean killing them if they are wrong? How would a Christian priest justify participation in war? Can this apparent contradiction be analogous to the doctor and capital punishment?

\section{The Doctor and Capital Punishment}

The aim of medicine is to promote the health of people, to protect their lives from disease and promote good livelihood. When doctors get involved in capital punishment the very existence of medical practice is challenged, or rather, medicine is challenged to justify its existence.

Many views are expressed in support of the non-involvement of doctors in capital punishment. This is derived from the Hippocratic Oath and medical ethics or code of practice for different medical organizations, international declarations and resolutions. "Primum non nocere" ... do no harm, and sustain life, are the two central tenets of medical teaching first codified in the Hippocratic oath, five centuries before the birth of Christ" (Crowley, 1986:16). Before being appointed, the doctor had to profess “...I will give no deadly medi- 
cine to anyone if asked, nor suggest any such counsel" (British Medical Association 1984:69).

In carrying out his duty to the patient, what should a doctor do? What should he not do? The British Medical Association has laid down rules in its handbook - 6.21 states that "it is unethical for a doctor to administer a drug to a prisoner for any purpose other than for his clinical care" (British Medical Association, 1984:45). And "A physician shall act only in the patient's interest when providing medical care which might have the effect of weakening the physical and mental condition of the patient" (British Medical Association, 1984:71).

Can doctors be called, in spite of their commitment to life, to serve the community in different capacities through their medical skills, to kill or injure their patients without moral difficulty? Are there higher goods which the doctors can pursue without moral problems, by killing or injuring their patients? In other words, do moral, social, religious or political considerations matter so much so that they can determine the doctor's bias against his duty to save lives?

The Geneva Declaration states that a medical practitioner has to say on taking up the job, I "WILL NOT PERMIT considerations of religion, nationality, race, party politics or social standing to intervene between my duty and my patient" (British Medical Association, 1984:72). Later the Tokyo Declaration stated that:

A doctor must have complete clinical independence in deciding upon the care of a person for whom he or she is medically responsible. The doctor's fundamental role is to alleviate the distress of his or her fellow men, and no motive, whether personal, collective or political, shall prevail against this higher purpose (British Medical Association, 1984:79).

The argument goes that to expect doctors to participate in capital punishment is to make them violate their duty to the patient on the grounds that the prisoner is a morally and socially unworthy character, which is not and should not be part of medicine. Siting the Nazi doctors as an example of how medicine can be misused, Muller-Hill has warned of the dangers and concluded that "The abandonment of the individual patient in favour of the group (community, nation) should always be resisted" (Muller-Hill, 1991:5).

Some doctors' involvement in murder trials have been condemned together with their involvement in capital punishment because "such participation in trials goes directly against the position of the American Psychiatric Association: The physician serving the state as executioner, either directly or indirectly, is a perversion of medical ethics and of his or her role as a healer" (Crowley, 1989:17).

Geiger has argued:

aside from the fact that it is a violation of the formally adopted rules of the AMA and virtually every other professional body, physicians are concerned with the protection and preservation of life. For physicians to participate in killing is a violation of the fundamental precepts of medicine (Geiger, 1991:8).

The question then raised is whether, given that the doctor should be committed to nothing else but the interest of his or her patient, there is no case for the view that such commitment is and should not be absolute? Surely, there may be reasons which can make it immoral for the doctor not to kill? Some people have given an affirmative answer to this question. That will be the subject of the following section. 


\section{In Pursuit of the Ideal - Justice}

\section{Justification of the Priests' Involvement in War}

The justification of the priests' involvement in war has been backed by reference to the Judaic tradition and the Old Testament where it has been shown that killing in the name of God or at his command is not only commendable but mandatory. With reference to the New Testament it has been pointed out that for example Jesus did not reject soldiers who came to him, a sign that he approved of the military. That is why "Christian priests may not shed human blood but themselves sometimes argue and teach that it is all right for Christian laymen to go to war" (Teichman, 1986:3).

Granted that there was no tradition of Christian involvement in war, let alone of priests, during the first century, there is something to the argument that at times priests can justifiably get involved in war. One argument is that a legitimate government can wage a just war like it can mete out punishment which is good both for the punished in some cases and for society. War can be likened to capital punishment. This view is held by Augustine.

This means that if priests and Christianity are for peace, war can be used to attain that peace through justice. This is the case especially if war is the only morally viable alternative to the attainment of peace. That is, priests would therefore be expected to take this route in pursuit of peace.

Alfonso Tostado has argued that:

just war is simply a mode of legal execution. ... Vitario says that, since St Paul says it is lawful for rulers to use arms against wrong-doers in the community, it must also be lawful to use arms against foreign enemies. ... Calvin, too, thinks that war and punishment are much the same thing. He says, for example, that killing soldiers in war is like exacting the death penalty on a criminal (Teichman, 1986:3).

Besides being used for justice, war can also be waged for the defence of a legitimate government. This happened for example, after Constantine's conversion when he had to be protected against his enemies.

The church can also be under attack as it is identified with a certain political authority when such authority is under fire. Archbishop Turpin of Rheims participated in a war and killed enemy soldiers. He argued that:

My Lords, barons, Charles left us here for this, He is our king, well may we die for him, to Christendom good service offering. Battle you and I have, you are all bound to it. For with your eyes you see the Saracens. Pray for God's grace, confessing Him your sins! For your souls' health I absolution give (Teichman, 1986:48).

Even though canonists like Gratian have argued for the prohibition of priests' involvement in war, "some canonists state that wars against enemies of God - pagans, heretics and infidels - are an exception to the rule; and indeed clergy accompanying the Crusades did wear armour and carry swords (Teichman, 1986:49).

So then, according to these arguments, a just war means a legitimate participation of priests in the war.

\section{Justification of Doctors' Involvement in Capital Punishment}

When executed in the case of murder, capital punishment is an example of justice whereby the guilty are made to suffer the consequences of their actions. Is it not fair then that the government should be helped to deal with the outlaws without violating their rights? It 
seems to be reasonable, so goes the argument, that the government must be helped to determine the psychological and physical fitness of the criminal to stand trial and to be executed so that justice may be done. This will ensure that psychological impediments to moral responsibility on the part of the criminal are removed for example, and psychiatrists are the people well suited to do this.

Once it is accepted that capital punishment is a just way of punishing certain deserving crimes, it does seem to be all right to expect doctors to help in the pursuit of justice. It would be unreasonable to expect medicine to be neutral and irresponsive to issues of justice because the vocation of medicine itself is founded on moral motives. That is, the feeling that it would be wrong not to help human beings with the skills of medicine is a moral intuition to say the least. So a very grave reason is necessary for moral insensitivity, should it be maintained in medicine.

This, however, cannot be the end of the story. There could still be a case for arguing that war is not justified but at a certain level the involvement of priests is morally justifiable. This can be said about the doctors and capital punishment. This is made pertinent by the fact that the involvement of doctors in capital punishment can make it more humane for the prisoner.

\section{Conclusion}

There does seem to be an analogy between the involvement of doctors in capital punishment and that of priests in war. For the two there is a prima facie contradiction between what they stand for and their involvement in war and capital punishment. However, there are situations which might justify the apparent abandonment of the basic principles of the two professions. The question which seems to arise for the two is whether in pursuing their principles they do not violate other morally important conditions presupposed by the profession. The question of obedience to legitimate authority seems to be important for the professions together with that of justice. I have not attempted to assess the claims by the opposing views about the involvement of doctors in capital punishment and that of priests in war.

\section{BIBLIOGRAPHY}

British Medical Association 1984. The Handbook of Medical Ethics. London: BMA. Cadoux, CJ 1919. The Early Christian Attitude to War: A Contribution to the History of Christian Ethics. London: Headley Bros. Publishers.

Crowley, M 1989. "Your life in their hands: Death by lethal injection has focused attention on the role of US doctors in executions." Amnesty April/May 1989: 16.

Geiger, T 1991. "Furor erupts after physicians assist in Illinois execution." Medical Ethics Advisor, January 1991:8.

Lackey, DP 1989. The Ethics of War and Peace. Englewood Cliffs, NJ: Prentice-Hall. Muller-Hill, B 1991. "Lessons from Nazi psychiatric practice". Bulletin of Medical Ethics 72, October 1991:5.

Teichman, J 1986. Pacifism and the Just War: A Study in Applied Philosophy. Oxford: Basil Blackwell. 